8

\title{
BORDERLANDS, FRONTIERS, AND BORDERS
}

\section{Changing meanings and the intersection with smuggling practices}

\author{
Sergio Peña
}

\section{Introduction}

The objective of this chapter is to contribute to the understanding of smuggling practices through the conceptual lenses of borderlands, frontiers, and borders. The analysis is based on the premise that smuggling is a multidimensional phenomenon that cannot be understood without considering its spatial and temporal dimensions, in which borders play a key role. Smuggling is an activity that thrives by taking advantage of structural differences of spaces, adjacent or not, for economic gains. The chapter analyzes specifically the intersection between smuggling and bordering practice.

It is important to clarify the meaning of three concepts that are used interchangeably in the literature: borders, borderlands, and frontiers. The three conceptual categories are not only economic, social, political, and cultural, but also spatial constructs that have meaning and content. Thus, the chapter dissects each category to search for its meaning and how it is linked to smuggling practice. The main question the chapter poses is: How does bordering affect smuggling practice?

The second section focuses on discussing how borders have been studied to have a grasp of theories and concepts that could help us explain how smuggling has been approached and defined through the different lenses of bordering practice. The main dimensions discussed are ontological and epistemological aspects related to the production of knowledge of borders, spatial and temporal conceptions of borders, borders and scalar notions, and borders and actors.

The third section discusses in more detail the intersection between bordering and smuggling. The main emphasis is on explaining how smuggling has adapted to the emerging practices of bordering in different epochs; for example, how smuggling changed with globalization and the notion of a borderless world, and how it has adapted to the post-9/11 world of security and rebordering.

There are two key arguments made throughout the chapter. First, borders are no longer understood as material, static, homogenous, and binary categories where a line separates and differentiates the "in" and "out," and the State determines what is allowed and what is proscribed. Second, borders instead are now understood as a social product that is heterogenous, 
polysemic, and dynamic where multiple actors are engaged in the process of creating meaning and symbolism. This chapter shows that perceptions and practices of smuggling have been affected by this emerging ontological and epistemological frame. New actors besides the State have emerged, the scope and scale have also changed, as well as the perception of smuggling and the smugglers from local folk heroes to transnational dangers.

\section{Borders, borderlands, and frontiers}

This section explores the meaning and definition of three concepts that often are used interchangeably in border literature. The main goal is to see if there are meaningful differences and to what extent those help us understand smuggling practice. I argue that even though there are some important differences in their meanings, the concept of borders has become the dominant one. Frontiers was used more to denote the expansion and control of newly acquired territories and it has lost importance as borders are settled and less likely to change. Borderlands is restrictive to a region, often defined by local or national governments, at the border and does not consider that bordering practices can take place away from the border line. The concepts of borderlands and frontiers have become less prominent because they are still grounded in what scholars (Agnew, 1994, 2008; Newman, 2006a, 2016; Paasi, 2012, 2014) call the classical notion of territorialism that assumes border as "fixed" and a material "thing." Additionally, it is argued that bordering practices can also be found in places not necessarily located at the international border line; the argument is that borders can be found "everywhere" (ÓTuathail, 1999; Balibar and Williams, 2002; van Houtum and van Naerssen, 2002; Lyon, 2005; Rumford, 2006) in places such as airports, highways, etc.

\section{Frontiers and borderlands}

The study of Frederick J. Turner originally published in 1893 was very influential in early works of frontiers (Stoddard, 1991; Newman and Paasi, 1998; Newman, 2001; Kraudzun, 2012). Turner's views on frontiers are closely related to the context of the American expansion and settlement of the West's "empty areas" (Baud and van Schendel, 1997, p. 213); Turner's view of the frontier is a cultural deterministic approach that separates the civilized and uncivilized cultures, particularly the white settlers from the native populations, a perspective that reinforces the view of natives as "out of step with modern society" (Stoddard, 1991, p. 2). Furthermore, House (1980, p. 459) states that frontier was a concept used in the diplomatic world and defines the frontier as a "buffer zone," often 10 kilometers in width on either side of the boundary. Peripherality is another dimension that is employed in the study of frontiers (House, 1980; Stoddard, 1991). House (1980) argues that frontiers face a double peripherality because looking at the frontier from both sides, two peripheral zones face each other.

According to Newman (2001), the study of the frontier moved away from the Turnerian cultural deterministic perspective towards a political problematization of the concept. The shift towards understanding the frontier as a political problem opened other views as well, including economics, administration, inter-state conflict, etc.

Finding a substantial difference in the conceptual definition of frontiers and borderlands in the literature is difficult; often they are used interchangeably. Stoddard (1991, p. 8) attempts to differentiate between the two, arguing that "border zone" and "frontier zone" have been used as synonyms, but the border zone normally is used to denote an administrative area whereas the concept of frontiers is fuzzy and not clearly defined. Because of the fuzziness (Newman, 2016) of defining frontiers scholars opted for the use of borderlands because it can offer a better 
conceptualization of the phenomenon. One advantage of using borderlands, according to Baud and Van Schendel (1997) is that the phenomenon can be approached through its "spatial dimension." Newman and Paasi (1998, p. 190) point out that the concept of borderlands allowed scholars to approach the topic from the perspective of "conflict, separation, partition and barriers" rather than "peace, contact, unification and bridges" which could open a new line of inquiry.

The above analysis shows that it is a futile exercise to try to define clearly the meaning and difference between frontier and borderlands. Scholars in recent years have instead opted for employing the concepts of borders and bordering for the following reasons. First and foremost, frontiers and borderlands are associated with the traditional positivist notion of geography as a physical object or "thing," thus overlooking the hermeneutic and subjective aspects of borders and meaning. Second, from the perspective of politics and international relations, borderlands were narrowly studied from a perspective of territorialism and conflict, facing the same limitations of what Agnew (1994) called the "territorial trap" (discussed in more detail in the next section). Third, the process of integration (e.g., European Union, North American Free Trade Agreement or NAFTA) and globalization during the 1980s that relaxed and softened borders forced us to conceptualize borders in a non-territorial way and problematize borders in hermeneutic and relational terms. Finally, the terrorist attacks of 09/11 revived the analysis of re-bordering and security, reinforcing the notion of borders as fortress.

\section{Borders and bordering practice}

The noun "border" and the verb "bordering," that denotes practice and action, have become dominant. Also, in the last few decades border studies have gained ground because of globalization processes that created interest in a "borderless world" (Newman, 2006b, 2016; Paasi, 2012). In the next paragraphs the concepts of border and bordering are scrutinized based on five categories: ontology and epistemology; spatial; temporal; scales; and actors. The aim is to explain how these categories help with our understanding of smuggling practice, which is the central purpose of the chapter. For instance, the section describes how smuggling is explained from a positivist versus a constructivist ontology of borders and what it means in terms of methodology.

The production of knowledge about borders has oscillated between two schools of thought positivist and constructivist - also referred to as scientific and hermeneutic approaches. Earlier studies of borders adopted an ontological view of "naturalized" borders or assumed that reality was independent of the social agents (Kolossov, 2005); physical geography became among the first fields to study borders from an objective perspective. The decision to engage or not in smuggling practice is modeled as a game theory where actors behave rationally and evaluate the probabilities of success and failure. Methodologically, the positivists focus on modeling and predicting flows across borders by applying models derived from the hard sciences such as physics; borders are usually incorporated as a distance or friction variable in the gravitational models. This approach had considerable influence in the globalization, international trade, and borderless world studies (ÓTuathail, 1999; Balibar and Williams, 2002).

Critical theory of border studies has relied on hermeneutical or interpretivist approaches; these studies consider the role of subjectivity in the formation of identity and narratives of differentiation, symbolism, and memory of border places (Newman and Paasi, 1998; Lapid 2001; van Houtum and van Naerssen, 2002; Newman, 2006a; Paasi, 2014). In short, the border is considered something that is socially constructed instead of being independent of the social agent's subjectivity (Kolossov, 2005). 
Borders are also analyzed from the perspective of space. The study of borders, from a spatial perspective, revolves around two approaches. On the one hand, there is the classical view of borders and space defined as the "territorialism perspective." The territorialism perspective is defined by the intersection of three categories: territory/sovereignty/borders. Agnew (1994, p. 59) identifies three key assumptions of territorialism: (1) territory and state are one and the same and have been "reified as a set of fixed units of sovereign space;" (2) studies focus on dichotomies such as national/international, domestic/foreign, overlooking some processes that operate at a more local and regional scale; and (3) "the territorial state has been viewed as existing prior to and as a container of society," ignoring local society's history. The idea of the state having all the tools and capability to keep the "container" self-enclosed and under control is one of the most criticized assumptions because borders are dynamic and fluid, not in stasis (Massey, 2005), and often the national and local interests do not work perfectly in tandem (Brunet-Jailly, 2005). Paasi (see Johnson et al., 2011) argues that instead of looking at borders as the domain of territorial sovereignty, the focus should turn to problematizing the relationship between state power and space, which is more visible at borders.

On the other hand, the relational view of space and borders incorporates issues of power and space as suggested above by Passi (2012). The relational view pays attention to social relationships and how these produced and reproduced space. Social networks are one specific tangible form of relational space (Paasi, 2012); borders are the site where a great multiplicity of social juxtapositions exist, characterized by movement and diversity rather than stasis and homogeneity (Massey, 2005; Johnson et al., 2011). Space is co-produced, renegotiated, and contested daily; culture, identity formation, and local social practice become subjects of the relational view.

A new emerging approach is "borderscapes" (Brambilla, 2015) and "borderities" (AmilhatSzary and Giraut, 2015) which, unlike territorialism, place the emphasis on the intersection of State/security/mobility. These studies rely on Foucault's concepts of biopolitics, and governmentality as spatial practice aimed at controlling, punishing, and disciplining bodies. ${ }^{1}$ The body or mobility of bodies (e.g., international migrants) is the subject of study, particularly how biometric technology has merged the border and the body to create data and algorithms for risk analysis (Lyon, 2005). Some studies (Balibar and Williams, 2002; Lyon, 2005; Rumford, 2006) have put forward the notion that borders are "everywhere," arguing that borders have become a-territorial/a-spatial; this is, functions traditionally thought to take place at the border (e.g., passport control, customs, surveillance, etc.) now happen in any location, such as airports, and city streets and become part of everyday life (Amilhat-Szary and Giraut, 2015), and how these bordering practices are resisted and subverted (Anderson and O’Dowd, 1999; Kraudzun, 2012).

The spatial dimension needs to be complemented with the time dimension that pays attention to history. One entry point to the time dimension is the evolutionist approach that sees progress as sequential and the new replacing the old; for instance, Marx's view of history as evolution of modes of production from slavery to capitalism. Another entry point is the timespace-social simultaneity where the new does not necessarily replace the old but rather they relate dialectically, and space and time are fluid rather than in a state of stasis (Soja, 1996; Massey, 2005). Earlier literature of borders focused on developing evolutionary typologies of borders; for instance, Martinez (1994), a historian himself, argues that borders move from alienated to coexisting then interdependent and finally integrated. Baud and van Schendel (1997) identify five evolutionary cycles - embryonic, adolescent, adult, declining, defunct.

Another temporal framework is to break time into modernism and post-modernism. The modern is the world that emerged from the renaissance where science and reason are the main sources of knowledge. The nation-State, according to Max Weber (2009), is an institution that 
modernity created to organize society by rational principles where efficiency is highly valued. According to ÓTuathail (1998) the modern view of borders is associated with the Westphalian nation-State system, and border studies reproduce the "territorial trap" assumptions (discussed earlier); the most important aspect to highlight is the notion that states have the monopoly or exclusive right over their territory, and they emphasize the role of the state as a source of administrating and imposing a spatial ordering to meet national interest goals. The post-modern view of the world challenges the "state-centric" approach and focuses on how non-state actors (e.g., corporations, mafias, gangs, terrorist organizations, etc.) make the container "leak" (Agnew, 1994) and move towards "deterritorialization" processes; in other words, from the post-modern perspective, national borders as material "things" or lines that separate are obsolete and thus borders need to be approached as social and economic processes that are "boundless."

Between the modern view of a "compartmentalized" world of sovereign states and the "borderless" narrative of post-modernism, there is the view of selective "de-territorialization" (Newman and Paasi, 1998; Lapid, 2001; van Houtum and van Naerssen, 2002; Newman, 2006b) arguing that the state still maintains the monopoly of territorial ordering by making the border easier to cross for some and harder for others, especially migrants with lower skills or human capital. van Houtum and van Naerssen (2002) referred to this as a process of bordering, ordering and othering. Finally, an alternative view is the one that argues that the discussion should move away from the temporal frame of modern/post-modern, and instead adopt Ulrich Beck's (1992) view of the risk society ${ }^{2}$ and focus on "de-territorialized threats" and "global dangers" (ÓTuathail, 1998) (e.g., terrorism, drugs, and human trafficking, etc.) across borders.

Border analysis from a scalar perspective moves among the notions of scale as a "container," fuzzy boundaries, and polycentric networks. The Russian dolls known as matryoshka are used as an analogy to illustrate the scalar notion of a container where one scale fits into another; the largest scale is the national, then the state, and the local is the lowest scale. Processes (economic, social, and political) are contained within those scales, and functions are divided in a hierarchical and functional way (Jessop, 2002). This scalar notion of a container is a normative "straw-man" model of how things ought to be within a political/administrative order. However, the container model crumbles with reality. Scales are often reconfigured by state and non-state actors who employ their power to re-order or re-scale processes to ensure the profitability of capital (Swyngedouw, 1997); scales become fuzzy, and power is polycentric across borders. In summary, the border moves from being a hard and well-marked edge or line around the container to an amorphous object for which it is hard to know where something starts or ends.

Finally, it is important to discuss border and actors. To uncover who the key border actors are, the important question is: Who borders and for what purpose? (Kolossov, 2005; Johnson et al., 2011; Newman, 2016). Border studies have demonstrated that the State is still an important actor that borders. However, new studies have shown that state and local governments as well as non-State actors (e.g., corporations, white supremacist organizations, immigrant advocates, etc.) are important; Cooper, Perkins and Rumford (2016) referred to this phenomenon as the "vernacularization" of borders. The discussion thus far has shown that one of the main actors in the bordering process is the State, since the Westphalian arrangement gave the State sovereignty powers and the monopoly to control its territory and borders (Agnew, 1994). However, the State is an abstract concept that is too limited to explore this issue more in depth. It is more important to explore who is in charge of administering the border and whether those agents are in tune with the State's goals (Brunet-Jailly, 2005). Border bureaucracies (Heyman, 1995) (e.g., border patrol, customs, immigration, army, navy, etc.) are important to study, including to what extent they have their own agenda and interests (e.g., likelihood of being corrupted, enforcing the law in a strict sense). 
Multi-national corporations and local business are also important actors that lobby for debordering. Asymmetries between neighboring countries often play an important role in the debordering process so that the border becomes a fixed locational asset (Boehmer and Peña, 2012). How border bureaucracies interact with economic forces is important to explore. Bureaucracies could be gatekeepers that enforce the law by the book. They could also facilitate exchanges by doing selective enforcement to their own benefit (rent-seeking predatory behavior) or simply be laissez-faire (Heyman, 1995). Border society in general is another important actor and the issues of identity and culture play a key role; society could ask for stricter enforcement of the border (narratives of differentiation and "othering") or make the border invisible due to shared values and identities ("usness") (van Houtum and van Naerssen, 2002). Social attitudes towards "deviant," "contesting" or "subversive" behaviors that often take place at the border are important to consider (Brambilla, 2015). For example, borders normally are associated with illegal activities so the question to explore is whether deviancy is rejected or embedded and part of the border social ethos (Baud and van Schendel, 1997). Lastly, while borders have become more and more difficult to cross for some populations, new actors are emerging in defense of human and civil rights that have been violated in the process of migrating (Brambilla and Jones, 2020).

\section{Borders, bordering and smuggling practice}

The focus in this section is on answering this research question: How does bordering affect smuggling practice? Smuggling is presented as a transgressive social practice that challenges borders and formal institutions. The intersection between border spatiality and smuggling also brings important insights. What follows is a discussion of three border approaches--the "territorialism" view, the relational view of borders, and the notion of borders "everywhere," or mobile borders. By using the conceptual categories (ontology and epistemology, spatial, temporal, scales, and actors) of the previous section, I unpack how smuggling and bordering have evolved.

The territorialism view of borders and smuggling points towards defining smuggling as a transgressive practice to the State's sovereign power and border control. The question that is often raised is: To what extent does the State have the capacity and resources to perform its panoptical function and prevent smuggling? An important track of analysis in this regard looks at bureaucracies as the front line or the most visible face of the State at the border. For example, Heyman (1994, p. 55) argues that "the networked and flexible organization of smugglers possesses significant advantages over bureaucratic action, especially in a boundary situation where smugglers have a safe zone." In short, from a territorialism perspective, the problem is framed as the contradiction of spatial "fixity" and the "fluidity" (Massey, 2005) of illicitness.

From a relational perspective of space, the focus is placed on the social relationships and networks created among smugglers, bureaucrats, and society. Territorialism assumes that the State and bureaucracies are in tandem and both work in perfect harmony, and the latter is professionally trained in the mirror image of Max Weber's rational organization; however, bureaucracies and State goals are not always on the same page. There are examples, particularly in the context of a weak or failed State, when bureaucracies act on their own interest as rentseeking, thus colluding with smugglers (Basu, 2014). van Schendel (2005. p. 51) defines this arrangement between bureaucracies and smugglers as the "pax mafiosa" and highlights two models of organization that show how smuggling and social networks operate at the border "the double-funnel" (abundance of people involved at the point of origin but few at the points of importation) and the "capillary pattern" (many people at the points of origin and destiny). 
In recent years, particularly after $09 / 11$, the idea of borders "everywhere" or "mobile" borders has gained ground in the literature (discussed earlier). This approach emphasized that the focus of the State shifted from controlling territory to assessing risk associated with mobility (people and goods). Border scholars (ÓTuathail, 1998; Balibar and Williams, 2002; Lyon, 2005; Rumford, 2006; Amilhat-Szary and Giraut, 2015; Brambilla and Jones, 2020) argued that as States adopt stronger security measures and surveillance functions (e.g., passport control, citizenship IDs, etc.) these are deployed in many locations away from international borders (e.g., airports, highways, neighborhood, etc.). The spillover effect of border securitization is the increasing costs of smuggling; therefore, the potential profits have attracted new players such as cartels and mafias that have either incorporated "local" smugglers or displaced them. The tactics of smugglers have become more violent, becoming "deterritorialized threats" and "global dangers" (ÓTuathail, 1998; Andreas, 2003), thus the social embeddedness between smugglers and society has been somewhat broken. Finally, as States re-territorialize their borders, enhance surveillance, criminalize smuggling (i.e., from misdemeanors to heinous crimes), and make the land border physically impossible to cross, smugglers "jump scales" and turn to other routes such as sea, air, and underground tunnels.

The attention now is turned to the temporal category and how the symbiosis between borders and smuggling has changed, particularly in the transition between modernity and postmodernity. The thread that links together the border and smuggling is the practice of bordering, particularly the dialectic between open and closed borders.

Within the modern epoch, the State used borders (regulating the flows in and out) to pursue a "national interest" of inward development and only traded to acquire inputs not found inside the nation. Empirical evidence shows that nations have developed at different rates and not in synchronicity. Thus, there can be borders where relative asymmetries are minimal (e.g., USA and Canada, Western Europe, Brazil and Argentina) or large (e.g., USA and Mexico, Brazil and Paraguay, Dominican Republic and Haiti); smuggling is present in both situations, but it is more intense where asymmetries are the largest. Smugglers take advantage of these asymmetries created by bordering practice or economic development policies (e.g., import substitution vs. export oriented). In brief, the modern approach is a State-centric in the sense that the State is the only actor with bordering capacity.

In contrast, the post-modern view is that multiple actors, in addition to the State, have the capability of re-bordering and de-bordering. For instance, transnational corporations' (TNC) revenue and stock value are higher than the entire gross domestic product (GDP) of some sovereign nations. While economies in the post-modern world became integrated and globalized, so did smuggling; as a matter of fact, drug smugglers re-organized into different organizational forms (e.g., cartels) and expanded the scale and scope of their activities (ÓTuathail, 1998; Andreas, 2002) and control substantial amount of financial resources. According to the World Economic Forum, drug smuggling accounts for half the assets of illicit economies and the financial assets are estimated at $\$ 320$ billion (equivalent to Colombia’s GDP of $\$ 331$ billion) (World Economic Forum WEF, 2016). Anti-immigrant and xenophobic groups have emerged in receiving countries and they have played a key role in re-bordering, therefore, smuggling, particularly human trafficking, has become the center of this re-bordering and criminalization.

Scales are also reconfigured by actors, including smugglers, who seek advantages in the debordering process. The important question to be addressed is: How do smuggling, borders, and scales interact and how have they changed? Several authors argue that borders are experiencing a phenomenon of "scale jumping" (Newman and Paasi, 1998; Abraham and van Schendel, 2005van Schendel van Schendel 2005; Rumford, 2006). This is, the traditional dichotomies of domestic/foreign, and national/international, according to Agnew (1994, p. 59), "obscure the 
interaction between processes operating at different scales." From a scalar perspective, smuggling practices have transformed their scope of action from local-local or cross-border regional to transnational. When smuggling becomes a transnational phenomenon, territorial borders (i.e., borderlands) lose their fixed locational advantages. Instead of being a central node in the flows of smuggled consumer goods such as cigarettes, electronics, etc., they become just another player in the wider and more complex network of transactions; smugglers could "jump scales" and bypass borders. Some border cities as commercial nodes of smuggled consumer goods have lost not only their fixed locational advantage but also the benefits of arbitrage economies were diminished with globalization and the opening of the economy; consumer goods can be shipped or transported without needing to cross a territorial border. The border as location is affected as well as the enterprise of smuggling goods that now are widely available through the formal economy at more competitive prices (Gereffi et al., 2009). Thus, smugglers must turn to other enterprises such as drugs and human trafficking. The points of origin and destination of smuggling activities have dispersed all over the map and involve a large constellation of actors dispersed across the world, making scales fuzzy.

According to Rumford, bordering is not always a business of the State; non-State actors are more and more engaged in this (see Rumford in Johnson et al., 2011). For instance, vigilantes or militia type organizations such as the "Minutemen" on the U.S.-Mexico border have asserted for themselves border patrolling functions. One extreme argument is that a "borderless" world meant the end of the State as we knew it in a post-Westphalian world. Another more moderate argument is that the State had never disappeared; it has just transferred some of its sovereign power to non-State actors to adapt to the new realities of the emergence of a transnational or global class (Sassen, 2007, pp.164-189) to manage the global network of capital accumulation. Simultaneously, with the emergence of a global class that often is associated with bankers, accountants, software developers, etc., there is also a global marginalized class that lives in global cities and keeps trying to cross the border (physical and economic) seeking a better life in more developed nations than their own. As receiving nations "re-border" their homelands, crossing borders has become more difficult for the marginalized class. Therefore, the cost of the journey has increased as has the need to use the services of smugglers who have turned into human traffickers. An important aspect to highlight is that the murky divide between smugglers (transporting goods that can be sold legally without coercion in the transaction) and traffickers (performing proscribed illegal activities and coercion exists) has disappeared. Smuggling as an enterprise has also undergone an organizational reconfiguration, becoming a transnational actor that controls large amounts of assets (\$2.1 trillion) and a wide network of operators who have diversified their economic portfolio (drug trafficking and human trafficking often are controlled by the same criminal organizations) (Andreas, 2002). Drug cartels are one example of how powerful these organizations have become, with substantial financial and war power that can challenge the State authority and its sovereignty over territory - including border points that are crucial to their enterprise. For example, some media outlets estimated that "El Chapo" Guzman, the most famous Mexican drug lord and head of the Sinaloa Cartel, now in prison in the U.S., has assets worth $\$ 12.6$ billion. As smuggling and trafficking become more profitable and wars among criminal organizations or terrorist acts have become more common, the notion of smugglers as folk heroes has been transformed into that of a societal menace and a "global danger” (ÓTuathail, 1998). 


\section{Conclusions}

This chapter has scrutinized the intersection between borders and smuggling, and it has revealed interesting connections between both. Borders as social constructs help us understand better the triad of smuggling practice, space, and society. The chapter shows that instead of looking at smuggling as a "deviant" or "subversive" practice that challenges the State authority and sovereignty over its territory, it is more fruitful and insightful to look at smuggling in relational terms which reveal how social relations and networks operate at the border to facilitate enforcement in a more selective way, mediating between local and national interests. Another relevant aspect reveals that smuggling as a social practice is not static but dynamic. Smuggling has adapted, for better or worse, not only in its "products and services," but also its organizational spatial structure linking border and non-border locations in a functional way. Smuggling and trafficking have taken advantage of globalization and transnational networks, some have become global criminal organizations capable of challenging the State and its control of borders. The conceptualization of borders spatially helps us to unpack and explain a variety of smuggling practices, providing a more complex and complete picture of the phenomenon.

\section{Notes}

1 Foucault studies the relationship power-space. The main argument is that space is one dimension where power is deployed with the objective of discipline and punishing subjects; spaces instead of being a utopia (imagined paradise) are transformed in heterotopias (existing, real, and nightmarish). Also, Foucault developed the term "governmentality" as an example of a power technology aimed to govern bodies, population, spaces, and movement.

2 Beck's central argument is that there is a break in history, and we are moving from modernity towards the risk society. The modern world shared the view that economic growth and prosperity were good for humankind, thus social values had some cohesiveness around these ideas. However, the risk society challenges the basic notion that growth is good and therefore social cohesion breaks down since risk, risk assessment and perception become central themes of political communities. Smuggling practice (e.g., drugs) and borders are often view as a risk or threat to the local population.

\section{References}

Abraham, Itty and van Schendel, Willem. (2005). Introduction: The Making of Illicitness. Willem van Schendel and Itty Abraham (Eds.), Illicit Flows and Criminal Things: States, Borders, and the Other Side of Globalization, 1-37. Bloomington, IN: Indiana University Press.

Agnew, John. (1994). The Territorial Trap: The Geographical Assumptions of International Relations Theory. Review of International Political Economy, 1:1, 53-80.

Agnew, John. (2008). Borders on the Mind: Re-framing Border Thinking. Ethics \& Global Politics, 1:4, 175-191.

Amilhat-Szary, Anne-Laure and Giraut, Frédéric. (2015). Borderities: The Politics of Contemporary Mobile Borders. Anne-Laure Amilhat-Szary and Frédéric Giraut (Eds.), Borderities and the Politics of Contemporary Mobile Borders. New York: Palgrave Macmillan, 1-22.

Anderson, James and O’Dowd, Liam. (1999). Borders, Border Regions and Territoriality: Contradictory Meanings, Changing Significance. Regional Studies, 33:7, 593-604, DOI: 10.1080/0034340995 0078648 .

Andreas, Peter. (2002). Transnational Crime and Economic Globalization. Mats Berdal and Monica Serrano (Eds.), Transnational Organized Crime and International Security: Business as Usual? Boulder: Lynne Rienner Publishers, 37-52.

Andreas, Peter. (2003). Redrawing the Line: Borders and Security in the Twenty-First Century. International Security, 28:2, 78-111. 
Balibar, Etienne and Williams, Erin M. (2002). World Borders, Political Borders. Publication of the Modern Language Association of America, 117:1, 68-78.

Basu, Gautam. (2014). Concealment, Corruption, and Evasion: A transaction Cost and Case Analysis of Illicit Supply Chain Activity. Journal of Transportation Security, 7:3, 209-226.

Baud, Michiel and van Schendel, Willem. (1997). Toward a Comparative History of Borderlands. Journal of World History, 8:2, 211-242.

Beck, Ulrich. (1992). Risk Society: Towards a New Modernity. Los Angeles: Sage.

Boehmer, Charles and Peña, Sergio. (2012). The Determinants of Open and Closed Borders. Journal of Borderlands Studies, 27:3, 273-285.

Brambilla, Chiara. (2015). Exploring the Critical Potential of the Borderscapes Concept. Geopolitics, 20:1, 14-34, DOI: 10.1080/14650045.2014.884561.

Brambilla, Chiara and Jones, Reece. (2020). Rethinking Borders, Violence, and Conflict: From Sovereign Power to Borderscapes as Sites of Struggle. Environment and Planning D: Society and Space, 38:2, 287-305.

Brunet-Jailly, Emmanuel. (2005). Theorizing Borders: An Interdisciplinary Perspective. Geopolitics, 10:4, 633-649, DOI: 10.1080/14650040500318449.

Cooper, Anthony, Perkins, Chris and Rumford, Chris. (2016). The Vernacularization of Borders. R. Jones and C. Johnson (Eds.), Placing the Border in Everyday Life, 15-32, New York: Routledge.

Gereffi, Gary, Spener, David and Bair, Jennifer. eds. (2009). Free Trade and Uneven Development: The North American Apparel Industry After NAFTA. Philadelphia: Temple University Press.

Heyman, Josiah. (1994). The Mexico-United States Border in Anthropology: A Critique and Reformulation. Journal of Political Ecology, 1:1, 43-66.

Heyman, Josiah. (1995). Putting Power in the Anthropology of Bureaucracy: The Immigration and Naturalization Service at the Mexico-United States Border. Current Anthropology, 36:2, 261-287.

House, John W. (1980). The Frontier Zone: A Conceptual Problem for Policy Makers. International Political Science Review, 1:4, 456-477.

Jessop, Bob. (2002). The Political Economy of Scale. Markus Perkmann and Ngai-Ling Sum (Eds.), Globalization, Regionalization and Cross-border Regions, 25-49. London: Palgrave Macmillan.

Johnson, Corey, Jones, Reece, Paasi, Ansi, Amoore, Louise, Mountz, Alison, Salter, Mark and Rumford, Chris. (2011). Interventions on Rethinking 'the Border' in Border Studies. Political Geography, 30:2, 61-69.

Kolossov, Vladimir. (2005). Border Studies: Changing Perspectives and Theoretical Approaches. Geopolitics, 10:4, 606-632.

Kraudzun, Tobias. (2012). From the Pamir Frontier to International Borders: Exchange Relations of the Borderland Population. Bettina Bruns Judith Miggelbrink (Eds.), Subverting Borders Doing Research on Smuggling and Small-Scale Trade, 171-191. Wiesbaden: Springer.

Lapid, Yosef. (2001). Introduction Identities, Borders, Orders: Nudging International Relations Theory in a New Direction. Mathias Albert, David Jacobson, and Yosef Lapid (Eds). Identities Borders Orders: Rethinking International Relations Theory, 1-20. Minneapolis: University of Minnesota Press.

Lyon, David. (2005). The Border is Everywhere: ID Cards, Surveillance and the Other. Elia Zureik and Mark B. Salter (Eds.), Global Surveillance and Policing: Borders, Security, Identity, 66-82. Portland: Willan Publishing.

Martinez, Oscar J. (1994). Border People: Life and Society in the US-Mexico Borderlands. Tucson: University of Arizona Press.

Massey, Doreen (2005). For Space. London; Thousand Oaks: Sage.

Newman, David and Anssi Paasi. (1998). Fences and Neighbours in the Postmodern World: Boundary Narratives in Political Geography. Progress in Human Geography, 22:2, 186-207.

Newman, David. (2001). Boundaries, Borders and Barriers: Changing Geographic Perspectives on Territorial Lines. Mathias Albert, David Jacobson, and Yosef Lapid (Eds.), Identities Borders Orders: Rethinking International Relations Theory, 137-151. Minneapolis: University of Minnesota Press.

Newman, David. (2006a). Borders and Bordering Towards an Interdisciplinary Dialogue. European Journal of Social Theory, 9:2, 171-186.

Newman, David. (2006b). The Lines that Continue to Separate Us: Borders in Our Borderless' World. Progress in Human Geography, 30:2, 143-161.

Newman, David. (2016). Contemporary Research Agendas in Border Studies: An Overview. The Routledge Research Companion to Border Studies, 55-70. London: Routledge. 
ÓTuathail, Gearóid (Gerard Toal). (1998). De-Territorialised Threats and Global Dangers: Geopolitics and Risk Society. Geopolitics, 3:1, 17-31, DOI: 10.1080/14650049808407605

ÓTuathail, Gearóid (Gerard Toal). (1999). Borderless Worlds? Problematising Discourses of Deterritorialization. Geopolitics, 4:2, 139-154, DOI: 10.1080/14650049908407644

Paasi, Anssi. (2012). Border Studies Reanimated: Going Beyond the Territorial/Relational Divide. Environment and Planning A, 44:10, 2303-2309.

Paasi, Anssi. (2014). The Shifting Landscape of Border Studies and the Challenge of Relational Thinking. Milan Bufon et al. (Ed.), The New European Frontiers: Social and Spatial (Re) integration Issues in Multicultural and Border Regions, 361-379. Newcastle: Cambridge Scholars Publishing.

Rumford, Chris. (2006). Theorizing Borders. European Journal of Social Theory, 9:2, 155-169.

Sassen, Saskia. (2007). A Sociology of Globalization. New York: W.W. Norton \& Co.

Soja, Edward. (1996). Thirdspace: Journey to Los Angeles and Other Real-and-Imagined Places. Cambridge, MA: Blackwell Publishing.

Stoddard, Ellwyn R. (1991). Frontiers, Borders and Border Segmentation: Toward a Conceptual Clarification. Journal of Borderlands Studies, 6:1, 1-22.

Swyngedouw, Erik. (1997). Neither Global nor Local: Glocalization and the Politics of Scale. Kevin R. Cox (Ed.), Spaces of Globalization: Reasserting the Power of the Local, 137-166. New York/London: The Guilford Press.

van Houtum, Henk and van Naerssen, Ton. (2002). Bordering, Ordering, and Othering. Tijdschrift voor Economische en Sociale Geografie, 93:2, 125-136.

van Schendel, Willem. (2005). Spaces of Engagement: How Borderlands, Illegal Flows, and Territorial States Interlock. W. van Schendel, and I. Abraham (Eds.), Illicit Flows and Criminal Things: States, Borders, and the Other Side of Globalization, 38-68. Bloomington: Indiana University Press.

Weber, Max. (2009). From Max Weber: Essays in Sociology. New York: Routledge.

World Economic Forum (WEF). (October 2016). State of the Illicit Economy: Briefing Paper. REF 290915, Geneva, Switzerland. 